\title{
Synthesis of Some New Fluorinated Fused Heteropolycyclic Nitrogen Systems Containing pyrazolo[3,4-d]pyrimidines Moiety and Their Effects on Cellobiase Activity Produced by Aspergillus nidulans Fungi
}

\author{
Dina A. Bakhotmah ${ }^{1 *}$, Reda M. Abdel-Rahman ${ }^{1}$, Montha fakhrji $^{1}$, Abrar kamal $^{2}$ \\ ${ }^{1}$ King abdul aziz uneversity, colleg of Scinece, chemistry departmaent, jeddah, Saudi Arabia \\ ${ }^{2}$ King abdul aziz uneversity hospital, Jeddah, Saudi Arabia \\ *Email: dbakhotmah@kau.edu.sa
}

\begin{abstract}
New Fluorinated fused heteropolycyclic nitrogen systems containing pyrazolo[3,4-d] pyrimidines moieties have been synthesized from the ring closure reaction of the corresponding hydrazine derivatives with bifunctional compounds. Structure of the new fluorinated systems obtained has been established from elemental and spectral analysis. The effect of these compounds was evaluated on the activity of cellobiase produced by Aspergillus nidulans fungi.
\end{abstract}

Keywords: Pyrimidines, fluoropyrazol, cellobiase activity, hydrazine derivatives.

\section{Introduction}

Recently, Hydrazine group bearing 1,2,4-triazines are used to synthesize an important heterocyclic nitrogen system with various functional group [1], in addition both the pyrazoles [2] and pyrimidines [3] exhibit medicinal, pharmacological and biological activities. The introduction of fluorine C-F and $\mathrm{CF}_{3}$ group to heterocyclic systems often improves and enhances their properties. Thus, this work tends to synthesize some more new fluorinated fused heteropolycyclic nitrogen systems containing pyrazolo[3,4d]pyrimidines moieties starting from hydrazine-pyrazolopyrimidines, in view of their effects on the cellobiase activity produced by Aspergillus nidulans fungi.

\section{Chemistry}

The 6-hydrazino-4-(4'-fluorophenyl)-3-methyl-1-phenylpyrazolo[3,4-d]pyrimidines (2) were obtained from hydrazinolysis of compound 1 [4]. Pyrimidine 2 is used as a starting material for building a number of fused polyheterocyclic nitrogen systems. Thus, ring closure reactions of compound 2 with triethyl orthoformat (TOF) in reflux tetrahydrofuran (THF) produced the pyrazolo $\left[4^{6}, 3^{6}: 5,6\right]$ pyrimido[2,3d] $[1,2,4]$ triazole 3 , while the reaction with diethylcarbonate or carbon disulfide in reflux DMF furnished pyrazolo $\left[4^{\natural}, 3^{6}: 5,6\right]$ pyrimido[2,3-c] $[1,2,4]$ triazole- 6 -one 4 and pyrazolo[ $\left[4^{6}, 3^{6}: 5,6\right]$ pyrimido[2,3-c] $[1,2,4]$ triazole -6-thione 5 (Scheme 1).

In addition, fused heteropolycyclic nitrogen systems 6 and 7 were obtained from the reaction of 1 with benzoic acid hydrazide or isonicotinic acid hydrazine in DMF under reflux (scheme 2). The nucleophilic attack of $\mathrm{NH}_{2}$ of acid hydrazide was followed by ring closure reaction by elimination of $\mathrm{H}_{2} \mathrm{O}$ molecule (figure 1). 


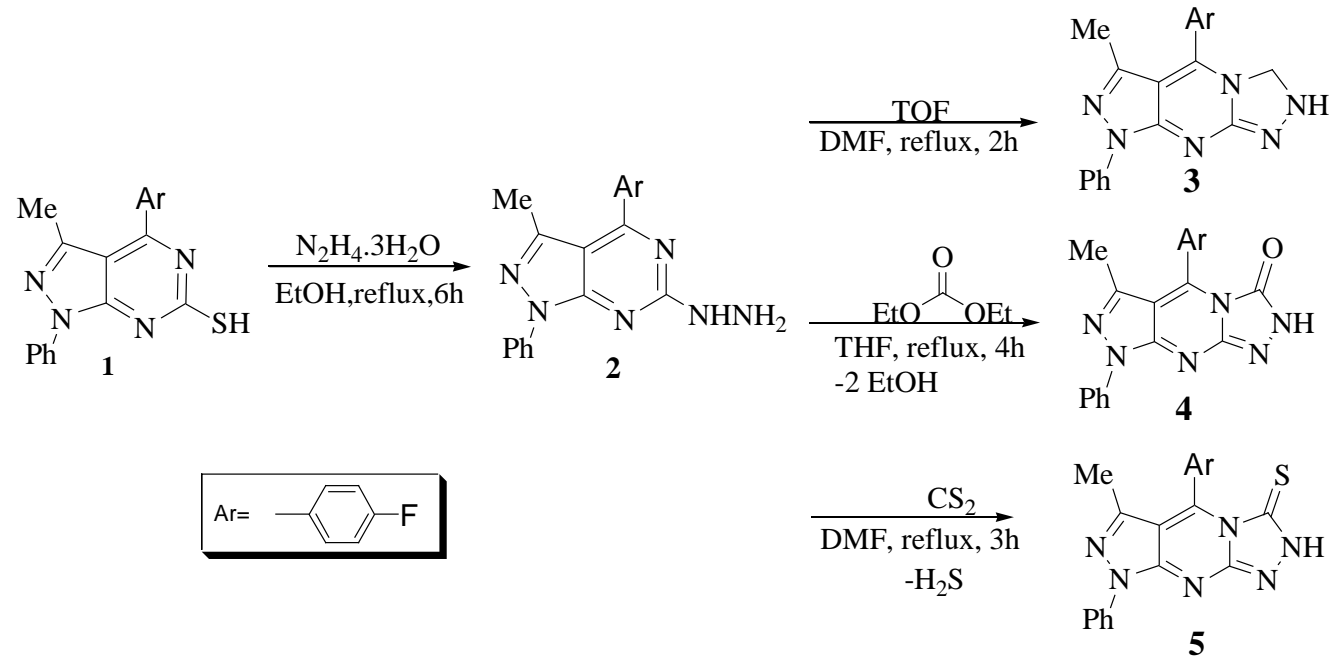

Scheme 1. Synthesis of triazole-6-one 4 and triazole-6-thione $\mathbf{5}$.<smiles>Cc1nn(-c2ccccc2)c2[nH]c(=S)nc([Al])c12</smiles>

5
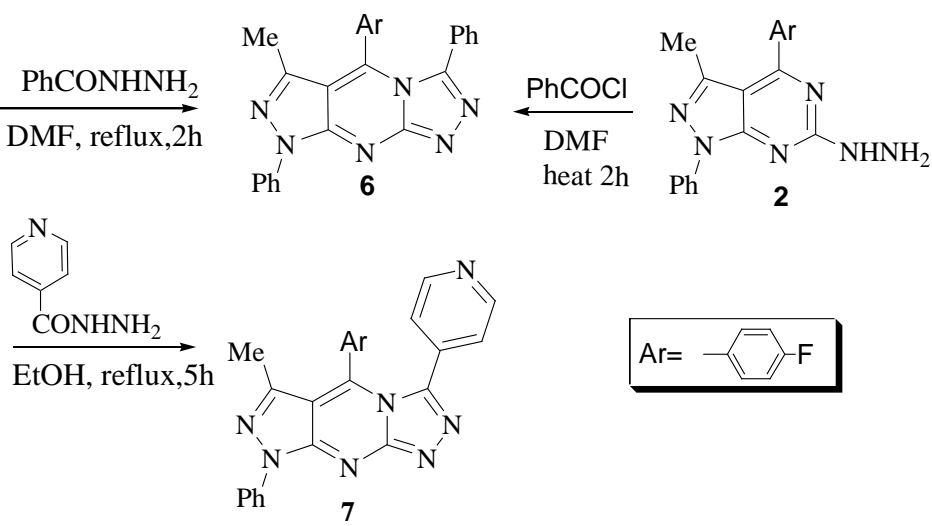

Scheme 2. Synthesis of fused heteropolycyclic nitrogen systems 6 and 7 .

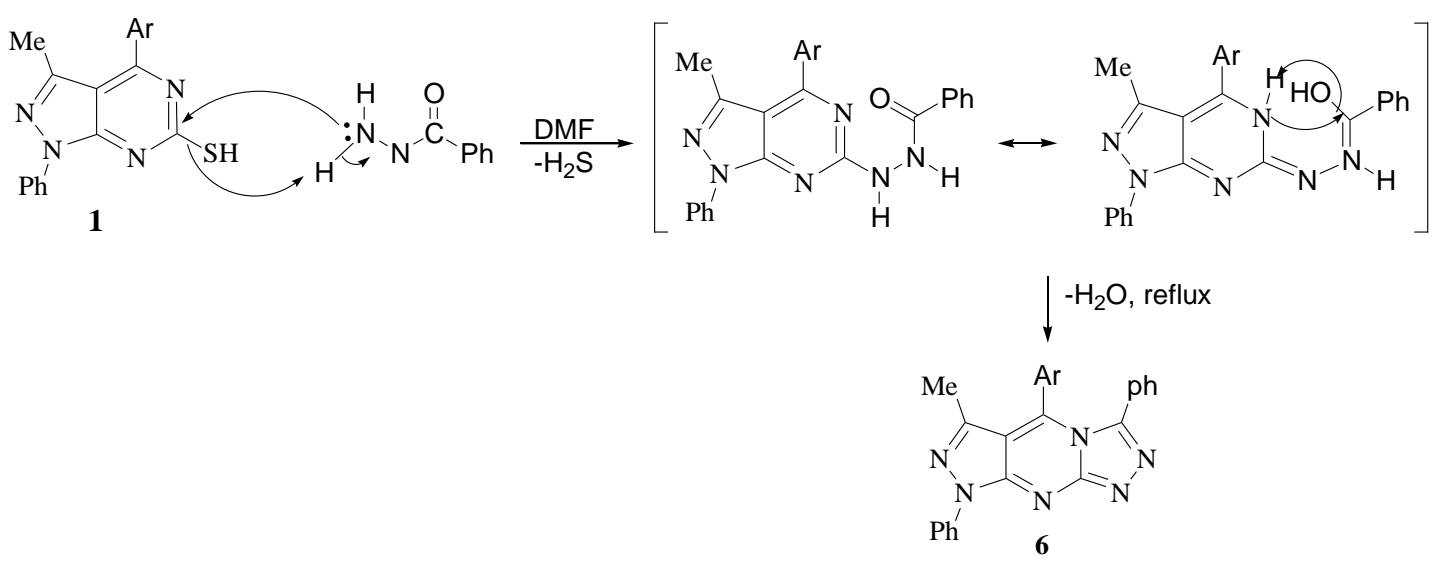

Figure 1. Suggested formation of compound 6 .

The nucleophilic attack of $-\mathrm{NH}_{2}$ dithioic formic acid hydrazide on mercapto group of compound 1 in DMF under reflux for $2 \mathrm{~h}$ gave $\mathrm{N}$-substituted-thiohydrazide 8. [5] The further Heterocyclization of compound 8 furnished compound 5 (scheme 3 ). 


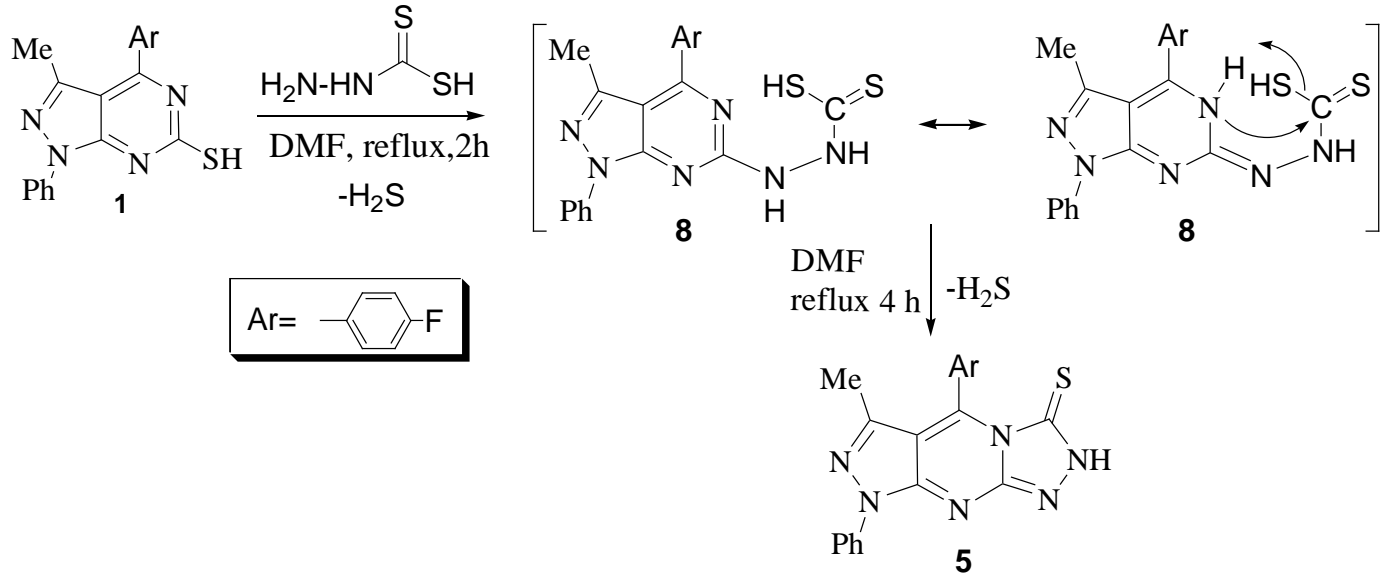

Scheme 3. Synthesis of N-substituted-thiohydrazide 8.

The hydrazo and azo compounds exhibit an important attention due to its application in the industry and agriculture field [6,7]. Thus, interaction between compounds 1 and 2 in isopropyl alcohol under reflux afforded the hydrazo-derivative 9, which upon simple oxidation gave the azo compound 10 . (Scheme 4).

\section{Result and Discussion}

The Ultraviolet (UV) spectrum for synthesis compounds 2, 3 and 4 showed $\lambda$ max at 430 (1.79), 437 $(0.35)$ and $540(0.85) \mathrm{nm}$. The fused heteropolycyclic nitrogen system bears both a chromophor and oxochrom probes. In addition, the hetero-conjugation systems formed enhance the $\lambda_{\max }$ of compound 4 in comparison with compound 2. The IR spectroscopy spectrum of new synthesized systems showed lakes of $-\mathrm{NH}_{2}$ functional group of 1,2,4-triazin at $3300 \mathrm{~cm}^{-1}$, compound 4 showed an interesting type of enolketo form systems exhibited at $V 1650-1620 \mathrm{~cm}-1$. On the other hand, compounds 5 and 8 recorded two functional groups $\mathrm{NH}$ and $\mathrm{C}=\mathrm{S}$ at $V$ 3300-3100 and 1180 respectively.

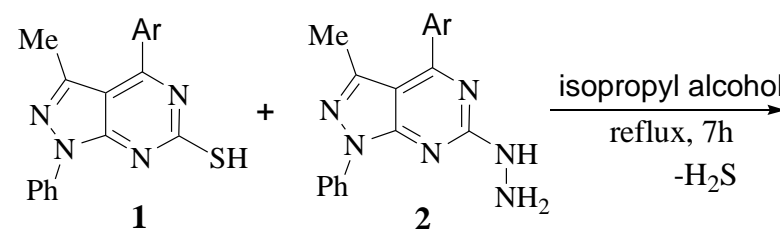

$A r=-F$<smiles>Cc1nn(-c2ccccc2)c2nc(NNc3nc(Br)c4c(C)nn(-c5ccccc5)c4n3)nc([Al])c12</smiles>

The hydrazo-compound 9

oxidation $\mid \begin{aligned} & \text { heat } 4 \mathrm{~h} \\ & \text { S/dry } \mathrm{C}_{6} \mathrm{H}_{6}\end{aligned}$<smiles>Cc1nn(-c2ccccc2)c2c(Br)nc(N=Nc3nc(Br)c4c(C)nn(-c5ccccc5)c4n3)nc12</smiles>

Scheme 4. Synthesis of azo compound 10 via hydrazo-derivative 9 oxidation. 
The ${ }^{1}$ HNMRspectrum of both compounds 4, 5 and 10 showed two broad singlet for NH proton at $\delta 9$ and $3.5 \mathrm{ppm}$, while compound 8 exhibited two different singlet for $\mathrm{NH}$ and $\mathrm{SH}$ protons at $\delta 8.5$ and 4.8 ppm respectively. Compounds 3, 6, 7 and 10 showed a lack of $\mathrm{NH}$ peaks.

Additionally, ${ }^{13} \mathrm{CNMR}$ spectrum showed as expected a various aliphatic and aromatic carbons at 14 , 129-125 and $\mathrm{C}-\mathrm{F}, \mathrm{C}=\mathrm{N}, \mathrm{C}-\mathrm{N}$ and $\mathrm{C}-\mathrm{C}$ carbons at $\delta 144,141,110 \mathrm{ppm}$ respectively. Only compounds 4 and 5 showed carbonyl $\mathrm{C}=\mathrm{O}$ and thionyl carbon $\mathrm{C}=\mathrm{S}$ carbons at $\delta 152$ and $162 \mathrm{ppm}$.

The mass fragmentation pattern of the fluorinated heterocyclic systems exhibited a base peak at $m / e$ 95(100\%), attribute to 4 -fluorophenyl radicals.

\section{Experiments}

Melting points determined with an electrochermal Bibly Sturat Scientific melting Point sample (UK). A Perkin Elmer Model RXI-FT IR system 55529 was used for Recording IR spectra of the prepared compounds (cm-1). A Bruker advance DPX 400 MHZ model using TMS as internal standard was used for recording the ${ }^{1} \mathrm{H}$ and ${ }^{13} \mathrm{CNMR}$ spectra of the compounds on DMSO- $\mathrm{d}_{6}$ (ppm). A GC-MS-GP 1000 Ex model was used for recording the mass spectra of the compounds $(\mathrm{MHz})$. Electronic spectra recorded in ethanol on Shimadzu UV and visible 310 IPC Spectrophotometer (nm). Elemental analysis was performed in micro analytical Center of Cairo University, Cairo, Egypt.

\section{6-Hydrazino-4- (4 '-fluorophenyl)-1-phenyl-3-methyl-pyrazolo[3,4d]pyrimidines (2)}

A mixture of $5(2 \mathrm{~g}, 6.0 \mathrm{mmol})$ and hydrazine hydrate $(100 \%, 0.516 \mathrm{~g}, 6.0 \mathrm{mmol})$ in EtOH $(40 \mathrm{ml})$ refluxed for $8 \mathrm{~h}$, cooled. The resulting solid collected by filtration and crystallized from EtOH to give compound 2 as orang crystals. Yield 93\%, m.p. 228-230 ${ }^{\circ}$ C. Analytical data; Found: C,64.51; H, 4.30;

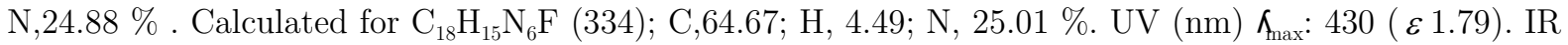
(cm-1) V: 3300, $3100\left(\mathrm{NH}_{2}, \mathrm{NH}\right), 2919$ (aliph. $\left.\mathrm{CH}\right), 1620$ (deformation $\left.\mathrm{NH}_{2}\right), 1610(\mathrm{C}=\mathrm{C}), 1591(\mathrm{C}=\mathrm{N})$, 1497 (deformation of $\mathrm{CH}_{3}$ ), 1217(C-F), 903, 787(ph). ${ }^{1} \mathrm{HNMR}(\mathrm{ppm}) \delta: 9.53(\mathrm{~s}, 1 \mathrm{H}, \mathrm{NH}), 7.92-7.82(\mathrm{~m}, 4 \mathrm{H}$, ar), 7.78-7.55 (s,1H,ar), 7.39-7.25 (d, 2H,ar), 1,24 (s,3H, CH3). ${ }^{13} \mathrm{CNMR}$ (ppm) $\delta: 144$ (C-F), 129.19 $(\mathrm{C}=\mathrm{N}), 129.07,128.94,128.89,127.68,126.66,126.03($ ar carbons, $99.66(\mathrm{C}-\mathrm{N}), 14.14(\mathrm{C}-\mathrm{CH} 3) . \mathrm{m} / \mathrm{s}=$ $352(\mathrm{M}+\mathrm{H} 2 \mathrm{O}, 1 \%), 95(100 \%)$.

1-Phenyl-3-methyl-4-(4`-fluorophenyl)pyrazolo[4`,3`:5,6]pyrimido[2,3-c] $[1,2,4]$ triazole (3)

A mixture of $14(0.4 \mathrm{~g}, 1.0 \mathrm{mmol})$ and TOF $(0.148 \mathrm{~g}, 1.0 \mathrm{mmol})$ in DMF $(27 \mathrm{ml})$ refluxed for $2 \mathrm{~h}$ and cooled. The resulting solid collected by filtration and crystallized from DMF to give compound 3. Yield 92\%, m.p.192-194 ${ }^{\circ}$ C. Analytical data; Found: C,66.00; H, 3.51; N,24.12 \%. Calculated for $\mathrm{C}_{19} \mathrm{H}_{13} \mathrm{~N}_{6} \mathrm{~F}$ (334); C,66.27; H, 3.77; N, 24.41\%. UV (nm) $\Lambda_{\max }: 430$ ( $\varepsilon$ 1.79). IR (cm-1) V: 2920, 2850 (aliph.CH), 1592, $1582(\mathrm{C}=\mathrm{N}), 1492$ (deformation of $\left.\mathrm{CH}_{3}\right), 1220(\mathrm{C}-\mathrm{F}), 903,788(\mathrm{ph})$.

4-Aryl-3-methyl-1-phenyl-1-pyrazolo $\left[4^{`}, 3^{`}: 5,6\right]$ pyrimido $[2,3-c][1,2,4]$ triazole-6- $(7 \mathrm{H})$ one $(4)$

A mixture of $14(0.6 \mathrm{~g}, 0.02 \mathrm{~mol})$ and diethyl carbonate $(0.236 \mathrm{~g}, 0.002 \mathrm{~mol})$ with tetrahydrofuran THF $(30 \mathrm{ml})$ refluxed for $4 \mathrm{~h}$, cooled. The resulting solid collected by filtration and crystallized from THF to give compound 4 as pale yellow crystal. Yield 91\%, m.p. 220-221 ${ }^{\circ} \mathrm{C}$. Analytical data; Found: C,62. 98;H, 3.55; N,23.01\%. Calculated for $\mathrm{C}_{19} \mathrm{H}_{14} \mathrm{~N}_{6} \mathrm{FO}(361)$; C,63.15; H, 3.87; N, $23.26 \%$. IR (cm-1) $\gamma: 3090(\mathrm{NH})$, 2919, 2849 (aliph. CH), $1650(\mathrm{C}=\mathrm{O})$ 1620, 1592,1582 (C=N), 1458 (deformation CH3), 1219 (C-F), 903,831 (ph). IR (cm-1) V: 3200-3400 (b, NH), 2920 (aliph. CH), 1592,1582 (C=N), 1498 (deformation CH3), 1366 (NCN), 1221 (C-F), 902,831 (ph). 1HNMR (ppm) 8: 7.90-7.915, 7.84-7.85 (each d, 2H, ar), 7.45-7.46 (m,5H, ar), 7.30, 7.28-7.29, 7.25-7.27(each s,2H, ar), 4.4 (s,1H,OH), 1,25 (s, 3H, $\left.\mathrm{CH}_{3}\right)$.

4-Aryl-3-methyl-1-phenyl-1-pyrazolo[4 $\left.4^{`}, 3^{`}: 5,6\right]$ pyrimido $[2,3-c][1,2,4]$ triazole-6- $(7 \mathrm{H})$ thion $(5)$

A mixture of $14(0.2 \mathrm{~g}, 0.6 \mathrm{mmol})$ and $\mathrm{CS}_{2}(0.14 \mathrm{~g}, 0.6 \mathrm{mmol})$ in DMF $(20 \mathrm{ml})$ refluxed for $3 \mathrm{~h}$, cooled. The resulting solid collected by filtration and crystallized from DMF to give compound 5 as yellow crystals. Yield 88\%, m.p. 184-185 ${ }^{\circ}$ C. Analytical data; Found: C,60.31; H, 3.55; N,22.00; S, $8.21 \%$. Calculated for $\mathrm{C}_{19} \mathrm{H}_{14} \mathrm{~N}_{6} \mathrm{FS}$ (377); C,60.47; H, 3.71; N, 22.28; S, 8.48\%. IR (cm-1) $\gamma: 3080(\mathrm{NH})$, 2850,2920 (aliph. CH), 1592,1608 (C=N), 1450,1498 (deformation of $\left.\mathrm{CH}_{3}\right), 1365(\mathrm{NCSN}), 1260$ (C-F), $1168(\mathrm{C}=\mathrm{S}), 788,903(\mathrm{ph}) .{ }^{1} \mathrm{HNMR}(\mathrm{ppm}) \delta: 9.53(\mathrm{~s}, 1 \mathrm{H}, \mathrm{NH}), 7.90-7.98,7.86-7.87$ (each d,2H, ar), 7.817.85, 7.60-7.79 (each s,2H,aromatic), 7.40-7.48 (m,4H,ar), 7.31-7.37, 7.29-7.30 (each d,2H, ar), 1.24 $\left(\mathrm{s}, 3 \mathrm{H}, \mathrm{CH}_{3}\right) \cdot{ }^{13} \mathrm{CNMR}(\mathrm{ppm}) \delta: 161.28(\mathrm{C}=\mathrm{S}), 138(\mathrm{C}-\mathrm{F}), 137(\mathrm{C}-\mathrm{F}), 129.19(\mathrm{C}=\mathrm{N}), 121.17,126.64,128.93$ (ar-C), 109 (C-C),12.93 (C-CH3). m/s (Int.y.): 379 (M+2, 3.1), 237 (5.11), 209 (13), 183 (21), 157 (18), $95(100)$. 


\section{2,6-Diphenyl-8-(4`-fluorophenyl)-9-methyl-pyrazolo[4`,3`:5,6]pyrimido[2,3-c] $[1,2,4]$ triazole}

(6)

A mixture of $14(0.4 \mathrm{~g}, 1.0 \mathrm{mmol})$ and benzoic acid hydrazide $(0.185 \mathrm{~g}, 1.0 \mathrm{mmol})$ in DMF $(25 \mathrm{ml})$ refluxed for $2 \mathrm{~h}$, cooled. The resulting solid collected by filtration and crystallized from DMF to give compound 6 as pale brown powder. Yield 94\%, m.p. 236-238 ${ }^{\circ}$ C. Analytical data; Found: C,71.30; H, $3.85 ; \mathrm{N}, 19.79 \%$. Calculated for $\mathrm{C}_{25} \mathrm{H}_{17} \mathrm{~N}_{6} \mathrm{~F}$ (420); C,71.42; H, 4.04; N, $20.00 \%$. IR $\left(\mathrm{cm}^{-1}\right) \quad \gamma: 2840,2917$ (aliph $\mathrm{CH}$ ), 1584,1617 (C=N), 1489 (deformation of $\left.\mathrm{CH}_{3}\right), 1203(\mathrm{C}-\mathrm{F}), 763,892(\mathrm{ph})$. 1HNMR (ppm) $\delta$ : 7.99-8.00, 7,09-7.89 (each d, 2H, ar), 7.90-7.98, 7.86-7.87 (each d,2H, ar), 7.43-7.45, 7.276-7.293, 7.2587.268 (each $\mathrm{m}, 12 \mathrm{H}$, ar), $1.25\left(\mathrm{~s}, 3 \mathrm{H}, \mathrm{CH}_{3}\right)$.

8-(4`-Fluorophenyl)-6-(pyridine-4` -yl)-2-phenyl-9-methylpyrazolo[ $\left.4^{`}, 3^{`}: 5,6\right]$ pyrimido[2,3-

c] $[1,2,4]$ triazole $(7)$

A mixture of compound $5(0.6 \mathrm{~g}, 2.0 \mathrm{mmol})$ and isonicotinic acid $(0.2 \mathrm{~g}, 2.0 \mathrm{mmol})$ in EtOH $(25 \mathrm{ml})$ refluxed for $5 \mathrm{~h}$ and cooled. The resulting solid was collected by filtration and crystallized from EtOH to give compound 7 as yellow crystals. Yield 70\%, m.p. 169-170 ${ }^{\circ} \mathrm{C}$. Analytical data; Found: C,71.30; H, $3.85 ; \mathrm{N}, 19.79 \%$. Calculated for $\mathrm{C}_{24} \mathrm{H}_{16} \mathrm{~N}_{7} \mathrm{~F}$ (421); C,68.40; H, 3.80; N, $23.22 \%$. IR (cm-1) $\gamma: 2849$, 2918.2955 (aliph CH), 1584,1591, $1616(\mathrm{C}=\mathrm{N}), 1488$ (deformation of CH3), 1203 (C-F),790-810 (phenyl). ${ }^{1}$ HNMR (ppm) 8: 7.99-8.00, 7,09-7.89 (each d, 2H,ar), 7.90-7.98, 7.86-7.87 (each d,2H, ar), 7.43-7.45, 7.276-7.293, 7.258-7.268 (each $\mathrm{m}, 12 \mathrm{H}$, ar), $1.25\left(\mathrm{~s}, 3 \mathrm{H}, \mathrm{CH}_{3}\right)$.

N-(Pyrazolo[4,3-d]pyrimidin-3-yl)dithioicformic acid hydrazide (8)

A mixture of $5(0.6 \mathrm{~g}, 2.0 \mathrm{mmol})$ and dithioic formic acid hydrazide $20(0.216 \mathrm{~g}, 2.0 \mathrm{mmol})$ in EtOH (30 $\mathrm{ml}$ ) refluxed for $4 \mathrm{~h}$, cooled. The resulting solid was collected by filtration and crystallized from EtOH to give compound 8 as yellow crystals. Yield 94\%, m.p. 163-164 ${ }^{\circ} \mathrm{C}$. Analytical data; Found: C,55.40; H, 3.55; N,20.33; S,15.40 \%. Calculated for $\mathrm{C}_{19} \mathrm{H}_{15} \mathrm{~N}_{6} \mathrm{FS}_{2}$ (410); C,55.60; H, 3.65; N, 20.48; S,15.60 \%. IR $\left(\mathrm{cm}^{-1}\right) \quad \gamma: 3300-3100(\mathrm{~b}, \mathrm{NH}), 2919$ (aliph CH), 1584,1615 (C=N), 1489 (deformation of CH3), 1203(CF), 1180 (C-S), 802,933 (ph). ${ }^{1} \mathrm{HNMR}$ (ppm) 8: 8.5, 9.0 (each s, 2H, NHNH), 7.91-7.92 (each d, 2H,ar), 7.898-7.899, 7.43-7.45 (each m,4H, ar), 7.28-7.29, 7.26-7.27, 7.25-7.26 (each s,3H, ar), 4.8 (s,1H,SH), $1.25\left(\mathrm{~s}, 3 \mathrm{H}, \mathrm{CH}_{3}\right) .{ }^{13} \mathrm{CNMR}(\mathrm{ppm}) \delta: 161(\mathrm{C}=\mathrm{S}), 152(\mathrm{C}-\mathrm{S}), 138.3(\mathrm{C}-\mathrm{F}), 137.58(\mathrm{C}=\mathrm{N}), 121.16,126.62$, 128.92 (ar carbons), 109 (C-C), $14.14\left(\mathrm{C}-\mathrm{CH}_{3}\right)$.

Pyrazolo $\left[4^{`}, 3^{`}: 5,6\right]$ pyrimido $[2,3-c][1,2,4]$ triazole-6-thione (5)

Compound $8(0.5 \mathrm{~g}, 1.0 \mathrm{mmol})$ and dry DMF $(25 \mathrm{ml})$ were refluxed for $3 \mathrm{~h}$, cooled. The resulting solid was collected by filtration and crystallized from DMF to give compound 5. Yield 94\%, m.p. 182-184 ${ }^{\circ} \mathrm{C}$. Synthesis of hydrazo-compound (bis-compound)1,2-Di-(1-phenyl-3-methyl-4-arylpyrazolopyrimidin-6-yl)hydrazine (9)

A mixture of compound $2(0.6 \mathrm{~g}, 2.0 \mathrm{mmol})$ and compound $2(0.6 \mathrm{~g}, 2.0 \mathrm{mmol})$ in isopropyl alcohol $(60$ $\mathrm{ml}$ ) refluxed for $6 \mathrm{~h}$, cooled and concentrated. The resulting solid collected by filtration and crystallized from ethanol to give compound 9 as yellow crystal. Yield 89\%, m.p. 250-252 ${ }^{\circ} \mathrm{C}$. Analytical data; Found: $\mathrm{C}, 67.64 ; \mathrm{H}, 3.85 ; \mathrm{N}, 21.89 \%$. Calculated for $\mathrm{C}_{36} \mathrm{H}_{26} \mathrm{~N}_{10} \mathrm{~F}_{2}(636) ; \mathrm{C}, 67.92 ; \mathrm{H}, 4.08 ; \mathrm{N}, 22.01 \%$. UV(nm) $\mathrm{h}_{\max }$ : 434 (V 1.60). IR (cm-1) $\gamma$ : $3150(\mathrm{NH}), 2980$ (aliph $\mathrm{CH}$ ), 2352 (aza N-N group), 1528,1590 (C=N), 1450,1498 (deformation of CH3), 1347 (NCN), 1230 (C-F), 810,908 (ph). ${ }^{1} \mathrm{HNMR}$ (ppm) 8: 7.80-7.85 (d,3H,aromatic), 7.53 (s,1H,ar), 7.49-7.51 (d, d, 2H, ar), 7.33, 7.34, 7.35 (each s,3H,ar), 3.41-3.5 (2H, $\mathrm{NHNH}), 1.25$ (s,3H,CH3).

\section{1,2-Diheteroaryl azo compound (10)}

A mixture of compound $9(0.6 \mathrm{~g}, 0.9 \mathrm{mmol})$ and sulphur powder $(0.028 \mathrm{~g}, 0.9 \mathrm{mmol})$ in dry benzen $(35$ $\mathrm{ml}$ ) was refluxed for $4 \mathrm{~h}$, cooled. The resulting solid collected by filtration and crystallized from benzene to give compound 10 as yellow powder. Yield $92 \%$, m.p. 245-246 ${ }^{\circ} \mathrm{C}$. Analytical data; Found: C,67.90; H,

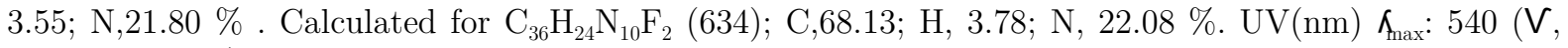
0.90). IR $\left(\mathrm{cm}^{-1}\right) \gamma: 2850,2915$ (aliph. $\left.\mathrm{CH}\right), 1867(\mathrm{~N}=\mathrm{N}), 1581,1591(\mathrm{C}=\mathrm{N}), 1482,1496$ (deformation CH3), 1335 (NCN), 1251 (C-F), 803,906 (ph). ${ }^{1} \mathrm{HNMR}$ (ppm) 8:7.89-7.90, 7.82-7.83 (each d,2H,ar), 7.43$7.48\left(\mathrm{~m}, 10 \mathrm{H}\right.$, ar), $7.33-7.35$ (d, $2 \mathrm{H}$, ar), $7.25-7.28\left(\mathrm{~m}, 4 \mathrm{H}\right.$, ar), $1.25\left(\mathrm{~s}, 1 \mathrm{H}, \mathrm{CH}_{3}\right) .{ }^{13} \mathrm{CNMR}(\mathrm{ppm}) \delta: 142$ $(\mathrm{C}-\mathrm{F}), 138.30(\mathrm{C}=\mathrm{N}), 137(\mathrm{C}-\mathrm{N}), 121.13,121.61,128.61,128.65,128.92,129.19,129.25$ (ar. carbons), 99.64 (C-C), 14.15 (C-CH3). m/s (Int.y.): 636 (M+2, 0.5\%), 303 (13), 208 (28), 156 (5.8), 312 (28), 95 (100), 52(5). 


\section{Biological Activity}

The electron withdrawing/ donating nature of heterocyclic nitrogen systems in diamine influences the nucleophility of the amino group [8]. In addition, fused heteropolycyclic nitrogen systems exhibit marked biological and pharmacological effects obtained from ring closure reactions of asymmetric diamines [9-10]. Moreover, presence of fluorine atoms enhances the biological activity. Accordingly, this work is aimed to evaluate the effects of fluorinated heterocyclic systems on the cellobiase activity of some fungi.

The effect of the newly synthesized fluorinated heteropolycyclic systems on the activity of cellobiase produced by Aspergillus Nidulans was studied according to the standard method. DMF was used as a solvent and a control, at $\mathrm{pH} 4.8-5$ incubated at $50{ }^{\circ} \mathrm{C}$ for 1 hour. The released reducing sugar was estimated calorimetrically at $540 \mathrm{~nm}$ as an indicator for the enzyme activity. The results obtained were recorded in Table 1.

Table 1. The effects of fluorinated hetero poly cyclic nitrogen systems on the cellobiase activity of A.N. Fungi Concentration.

\begin{tabular}{lllll}
\hline Nitrogen & \multicolumn{3}{c}{ Concentrations } & $\begin{array}{l}\text { Compound } \\
\text { number }\end{array}$ \\
\cline { 2 - 4 } Percent \% & $\mathbf{1 0} \mathbf{~} \mathbf{g} / \mathbf{m l}$ & $\mathbf{1 0 0} \mathbf{~} \mathbf{g} / \mathbf{m l}$ & $\mathbf{1 0 0 0} \mathbf{~} \mathbf{g} / \mathbf{m l}$ & 14 \\
\hline 25.1 & 0.33 & 0.35 & 0.37 & 15 \\
24.41 & 0.34 & 0.36 & 0.38 & 16 \\
23.26 & 0.31 & 0.35 & 0.36 & 19 \\
23.27 & 0.30 & 0.30 & 0.35 & 22 \\
22.01 & 0.35 & 0.36 & 0.41 & 23 \\
22.08 & 0.35 & 0.37 & 0.45 & \\
\hline
\end{tabular}

* Blank: $0.35 \mu \mathrm{g} / \mathrm{ml}$ (without substance or DMF).

** DMF: $0.04 \mathrm{\mu g} / \mathrm{ml}$ as solvent.

From the results obtained in table 1 we conclude that the overall activities of the tested compound are $10>9>2>3>4>6$, the highly activity of compounds 10 and 9 may be due to a higher nitrogen percent and the present of fluorine atoms. Thus the increasing of nitrogen percent in the active systems possibly enhances their activity.

\section{Conclusion}

This investigation reported a novel synthetic application toward an interesting fluorine substituted fused heterocyclic nitrogen systems via ring closer reactions of hydrazinopyrazolopyrimidine with bifunctional compounds. These synthesis systems were evaluated as enzymatic effects towards cellobiase activity

\section{References}

1. R. Abdel-Rahman, A. Asiri, A. Khan, "WITHDRAWN: Reactivity of 3-hydrazono-1,2,4-triazines towards various strong electrophiles-Synthesis of heteropolycyclic nitrogen systems Targets a review". Arabian Journal of Chemistry, vol. 8, pp 800-812, 2013.

2. D. Bakhotmah, R. Abdel-Rahman, "A Review on the Synthesis and Chemistry of Bioactive Pyrazolines Bearing 1,2,4-Triazine Moieties", Mini Rev. Org. Chem., vol. 13, no. 1, pp. 62-77, 2016.

3. M. Makki, D. Bakhotmah*, R. Abdel-Rahman, M. El-Shahawy, Designing and Synthesis of New Fluorine Substituted Pyrimidine-Thion-5-Carbonitriles and the Related Derivatives as Photochemical Probe Agents for Inhibition of Vitiligo Disease, International Journal of Organic Chemistry, vol.2, pp. 311-320, 2012.

4. D. Bakhotmah, R. abdul-rahman, Montha fakhorji, Synthesis and chemical reactivity of some new fluorine substituted pyrazolopyrimidine derivatives and their effect on cellobiase activity produced by fungi, World Journal of Organic Chemistry, Vol. 5, no. 1, 2017.

5. R. Abdel-Rahman, M. Makki, A. Al-Romaizan, Synthesis of Novel Fluorine Substituted Isolated and Fused Heterobicyclic Nitrogen Systems Bearing 6-(2'-Phosphorylanilido)-1,2,4-Triazin-5-one Moiety as Potential 
Inhibitor towards HIV-1 Activity. International Journal of Organic Chemistry. vol. 4, 247, 2014.

6. A. Abdelhamid, A. Elghandour, A. Hussein, Y. Zaki, Reactions of Hydrazonoyl Halides 41:1Synthesis of 1,2,4Triazoles, 2,3-Dihydro-1,3,4-thiadiazoles, and Triazolo[4,3-a]pyrimidines. Phosphorus, Sulfur, and Silicon and the Related Elements. Vol. 180, pp. 2097-2109, 2005.

7. P. Bhardwaj and N. Gupta, "1,2,4,5-Tetrazines as Platform Molecules for Energetic Materials and Pharmaceuticals", Iranian J. Org. Chem., vol. 8, no. 3, pp. 1827-1831, 2016.

8. J. W. Fronabarger, R. D. Chapman, D. Gilardi, "Facile entry into the 3H,9H-bis[1,2,4] triazolo-[1,5-a:5,1d] $[1,3,5]$ triazinium (5/6/5 tricyclic NNN) system", Tetrahedron Letters, vol. 47, Issue 44, pp. 7707-7709, 2006.

9. D. Bakhotmah, "Synthesis of Novel $\alpha$-Amino Acids Bearing 1,2,4-Triazinone and Steroidal Moieties as Enzymatic Affects (Cellobaiase Activity) - Part II" Current Organic Synthesis, vol. 12, pp. 1-7, 2012.

10. M. Ibrahim, R. Abdel-Rahman, A. Abdel-Halim, S. Ibrahim, H. Allimony. "Synthesis, Chemical Reactivity and Fungicidal Activity of Pyrido[1,2-b][1,2,4]triazine Derivatives". J. Braz. Chem. Soc, vol. 20, no. 7, pp. 1275-1286, 2009. 